\title{
Den teologiske modtagelse af Verdenskrøniken 1812
}

\author{
Af Kim Arne Pedersen
}

Udsendelsen af $V K 1812$ førte Grundtvig ind i en række stridigheder med samtidige intellektuelle og isolerede ham i dansk åndsliv gennem en længere årrække. Almindeligvis har forskningen fokuseret på hans modsætningsforhold til personer, der stod under påvirkning fra den tyske idealisme. Grundtvig førtes imidlertid også ud i en række debatter med samtidige teologer, der var præget af tysk oplysningsteologi. Centralt i debatterne står spørgsmålet om forholdet mellem fornuft og åbenbaring, herunder muligheden for at forene kantiansk filosofi med supranaturalistisk teologi. Debatterne nuancerer billedet af Grundtvig som idealismens kritiker og viser, at det 19. århundredes første tiår ikke udelukkende kan karakteriseres ved hjælp af de danske varianter af den tyske idealisme.

\section{Indledning: Grundtvig og guldalderen}

Inden for Grundtvigforskningen har man almindeligvis fortolket Grundtvigs forfatterskab gennem en sammenligning med, hvad man opfatter som hovedstrømningen i Grundtvigs samtid, en sammenligning, hvor modsætningen mellem Grundtvig og hans samtids tænkemåde betones. Almindeligvis bygger kontrasteringen på en bestemmelse af den tyske idealisme og dens danske varianter som de teoridannelser, der muliggør en periodekarakteristik. Kontrasteringen sigter således mod at gribe fat i de faktorer, der giver perioden dens grundpræg i forhold til på den ene side den forudgående oplysningstid, på den anden side Det moderne Gjennembrud, dvs. den bestræbelse på at indføre en realistisk litteratur med frihed og fremskridt som nøgleord, som litteraturhistorikeren Georg Brandes (1842-1927) i 1871 gør sig til talsmand for. I Grundtvig og grundtvigianismen $i$ nyt lys, den hidtil uovertrufne akademiske introduktion til Grundtvigs forfatterskab, udkommet på dansk og tre fremmedsprog ved Grundtvigjubilæet i 1983, fremhæver William Michelsen idealismens indflydelse på teologi og kristendomsopfattelse:

\footnotetext{
Perioden 1800-1870, som man har kaldt "guldalderen i dansk litteratur", var gennemgående præget af et forlig mellem kristendom og videnskab, bygget på Kants og hans efterfølgeres filosofi. Det forudsattes, at kristendommen lod sig forlige med en idealistisk filosofi, først i Henrik Steffens' "Indledning til philosophiske Forelæsninger" 1802-03, siden i H. C. Ørsteds dialoger og populære skrifter, udgivet 1849 under titelen "Aanden i Naturen" (...) J. P. Mynster protesterede mod sin ven Ørsted fra luthersk side, men fik svar af Ørsted i 2. del af "Aanden i Naturen" (Michelsen 1983b, 290).
}

Brandes' forelæsninger afgrænser perioden, men i Michelsens karakteristik af det nittende århundredes første to tredjedele klinger debatten 
om tro og viden også med, dvs. den debat, som filosoffen Rasmus Nielsen (1809-84) rejste, og hvor han argumenterede for videnskab og religion som absolut uensartede principper. Periodekarakteristikken forudsætter en etableret opfattelse af, hvad der udmærker det 19. århundrede, men det angives ikke, hvilke vurderingskriterier der ligger til grund for den. Er det de synspunkter, der deles af de fleste indenfor de intellektuelle miljøer i Danmark, der giver perioden dens grundpræg, er det de tanker, der er nye i forhold til den foregående epoke, eller er det ideer, som lader sig fortolke ud fra et implicit eller eksplicit historiesyn? Iscenesættelsen af det nittende århundredes første to tredjedele, og her især århundredets første tiår, som en afgørende periode i dansk åndsliv har bl.a. litteraturhistoriske studier af Vilhelm Andersen (1864-1953) som baggrund og har haft kanonisk status som kulturelt grundlag for dansk national identitet. Guldalderens litteratur og historie har op til vor tid stået stærkt i den litterære kanondannelse og dansk historieundervisning, et forhold, der alle forskelle til trods minder om "Goethetidens" status i tysk åndshistorisk forskning og kulturpolitik i tiden frem til Anden Verdenskrig. ${ }^{1}$ William Michelsens periodekarakteristik forudsætter Vilhelm Andersens arbejde, men adskiller sig grundlæggende herfra ved at fokusere på det teologiske element i Grundtvigs forfatterskab i mere eller mindre udtalt sympati for Grundtvig som "sin samtids kritiker" (Michelsen 1983c, 7). Hos Michelsen gennemføres en stilisering, der gør idealismen til den periodekonstituerende strømning, det afgørende idekompleks, der giver "guldalderen" dens grundpræg. Dette forhold danner baggrund for Grundtvigs fremtræden efter omvendelsen i 1810 som en radikalt anderledes tænker i forhold til samtidens syntese af tro og viden, og her spiller debatterne efter Grundtvigs Kort Begreb af Verdens Krønike betragtet i Sammenhoeng 1812 (VK 1812) en afgørende rolle. I den førnævnte introduktion til Grundtvigs forfatterskab skildrer Michelsen modtagelsen af $V K$ 1812:

Grundtvigs forfatterskab i disse år forandrede totalt hans stilling i samtidens litteratur. Han blev en yderst omstridt mand. En af hans nærmeste venner,

\footnotetext{
${ }^{1}$ Lighederne er ikke tilfældige: Vilhelm Andersen læste, som Per Dahl (Dahl 2002 og 2010) gør rede for det, sin samtids tyske åndshistorie, og i hans reception møder man den interesse for åndshistorie som nationalt grundlag, der spiller en væsentlig rolle i tysk åndsliv fra det tyvende århundredes begyndelse og frem til afslutningen på det nationalsocialistiske diktatur og det efterfølgende nybrud i tysk kultur. Baggrunden er Tysklands nederlag i Første Verdenskrig, der fører til, at tysk åndshistorie med tidsskriftet Deutsche Vierteljahrschrift für Literatur und Geistesgeschichte arbejder på basis af en "nationalistische Definition des Geistbegriffs" (Seeba 1993, 247). For Vilhelm Andersen er Oehlenschlägers forfatterskab periodens største frembringelse. I Grundtvig ser han det dybeste udtryk for den danske "Aands Kamp for at blive sig selv bevidst" (Andersen 1924, 141).
} 
historikeren Molbech, tog offentlig afstand fra ham; og fysikeren H. C. Ørsted angreb navnlig Grundtvigs dom over naturfilosoffen Schelling i bogen "Kort Begreb af Verdens Krønike" 1812. Andre fandt det oprørende, at han vovede at angribe endnu levende personer i en "Verdenskrønike"! (Michelsen 1983a, 48).

Michelsen fortsætter med at gøre rede for, hvorledes "Verdenshistorien" ifølge VK 1812 er "menneskets frelseshistorie", og hvorledes Grundtvig "i disse år" "hævdede" "en enhedskultur, der var virkelig kristen og ikke blot en kristeligt farvet idealisme" (49) - sådan som det var tilfældet hos flere af Grundtvigs modstandere.

\section{Grundtvigs stridigheder med Chr. Molbech og H. C. Orsted}

Michelsens fremstilling har ensidighedens styrke i sin kontrastering af Grundtvig og idealisterne, men forbigår en række betydelige kritikere af Grundtvig. Derimod er hans redegørelse præcis, når det gælder det "før" og "efter", som VK 1812 markerer i Grundtvigs forfatterskab. Og samtidig med, at idealisterne langtfra er de eneste, der kritiserer Grundtvig, er det med god grund, han inddrager to af Grundtvigs modstandere fra denne lejr. Grundtvig mødte modstand fra idealistisk påvirkede skribenter gennem kritikken fra ungdomsvennen, historikeren Christian Molbech (1783-1857), som Grundtvig efter bruddet i 1813 først fik forbindelse med igen i 1820' erne, og naturforskeren H. C. Ørsted (1777-1851), der af Michelsen med rette tildeles rollen som den idealistiske filosofis forsvarer overfor Grundtvigs angreb. Molbech kritiserede efter VK 1812 Grundtvigs for ham at se søgte og forskruede kristne historieskrivning, Ørsted kritiserede hans angreb på de kantianske og efterkantianske filosoffer, dvs. den tyske filosof Immanuel Kant (1724-1804) og de idealistiske filosoffer Johann Gottlieb Fichte (1762-1814) og Friedrich Wilhelm Joseph Schelling (1775-1854). Michelsen har da også ret i, at Grundtvig imødegår begge modstandere ved at lede striden hen på spørgsmålet om Molbechs og idealisternes forhold til kristendommen. Efter Molbechs offentlige kritik af $V K 1812$ skriver Grundtvig i modskriftet Krønikens Gienmole:

Hvad der egentlig har vakt din Harme over Bogen er, at Du ikke troer paa Christus, som Guds eenbaarne Søn, Kongernes Konge og Herrernes Herre, at Du ikke troer Apostlenes og Propheternes Tale som guddommelig, usvigelig Sandhed, og derfor ikke kan lide at jeg har opkaldt Tiderne til at vidne om hvorledes Gud har beseiglet sin Søn og sit Ord (Grundtvig 1813a, 4).

Af Molbechs svar fremgår det, hvor stor afstanden mellem de to er. For Grundtvig er kristendommen absolut sandhed, for Molbech udgør den den højeste religionsform blandt verdens religioner. Grundtvigs 
kristendom er guddommelig åbenbaring, Molbechs er en lære, der kan indordnes $i$ en systematisk oversigt over andre former for religiøsitet. Molbech svarer 24. juli 1813 i NKjSk i en erklæring til den læsende almenhed bl.a.:

Ikke, at han paa sin Viis har søgt at ophøie Christendommen, som jeg i mit Svar paa Grundtvigs Brev Nr. 12 har erkiendt for den høieste og guddommeligste Religionslore, Tiden har seet - har vakt min Harme; men at hiin saakaldte Verdens Krønike, med alle sine Mangler og Feil, med sin slet udførte Plan og sin ufuldkomne Form, forkyndte sig med uhørt Stolthed som Verdens og Tidernes Dommer, under hvis Fødder Tidsalderne skulde bøie sig, og deres største Mænd lægge Hovederne ned, for at trædes paa (her fra Molbech/Schrøder 1888, 126).

At tale om en kristeligt farvet idealisme er da ikke uberettiget, når det gælder Molbechs religiøsitet, og også Ørsteds teologiske stade er et lignende. Det fremgår, når han tager stilling til Grundtvigs strid med den teologiske professor Jens Møller (1779-1833) og da med henblik på Kants tænkning skriver:

Hvad maa vel den underrettede Læser tænke, naar han hører at Rec. opfordres til at bevise, at der i vor Tidsalder, før Grundtvig optraade, en fornyet Straben mod det Guddommelige hos mange af de høiere begavede Aander havde viist sig? Skal man da i en litterarisk Strid, bevise Ting, som enhver, der ei er fuldkommen ukyndig i de sidste 30 Aars Litteratur veed? Skal jeg da fortælle ham, hvad der er ham vel bekjændt, at Kant bidrog meget til at gjenvække sand Religiøsitet, ved at omstøde alle de materialistiske Systemmer [sic], ved at vise Datidens eudaimonistiske Moralphilosophie i dens hele Skadelighed, ved at overbevise mange af sin Tidsalders Mennesker om, at al grundig Undersøgelse over Mennesket og Verden peger tilbage paa en høiere Kreds, der kun med Tro kan omfattes? Tør man ikke kalde dette en herlig Stræben fra en vantro ensidig Oplysning til en dybere religiøs Følelse? (Ørsted 1814, 41 f.).

Ørsted taler om religiøsitet $\mathrm{i}$ almindelighed, filosofisk farvet religiøsitet. Grundtvig svarer ham i skriftet Imod den lille Anklager, det er H. C. Ørsted: med Beviis for at Schellings Philosophie er uchristelig, ugudelig og løgnagtig gennem et angreb på Kants filosofi, her først og fremmest Kants rationalistiske omtolkning af kristendommen til, hvad han betegner "Der reine Vernunftglaube" (Kant 1794/1922, 194). I angrebet vender Grundtvig Ørsteds kritik mod denne selv:

Skal jeg i en litterarisk Strid fortælle, hvad Skolepogen veed, at Kant ikke viisde til, men fra Troens Hemmeligheder, at det var med hans Sætninger Troens Lærdomme stærkest bekiæmpedes, at den christelige Moral ogsaa af ham sigtedes for Eudaimonisme (Grundtvig 1815a, 46).

Grundtvig bliver dog samtidig ikke stående ved denne bedømmelse af Kant. Han er i 1812 og i årene derefter optaget af muligheden af at kombi- 
nere kantiansk dragen grænser for erkendelsen med sin egen kristentro og skriver derfor videre:

Kant indsaae klart, at naar Fornuften i Selvstændighed (som blot theoretisk) forsteeg sig til det Oversandselige, gik det den som Goethe saa sandt og skiønt synger om Mennesket:

Hebt er sich aufwärts,

Und berührt

Mit dem Scheitel die Sterne,

Nirgends haften da,

Die unsichern Sohlen,

Und mit ihm spielen

Wolken und Winde.

Han indsaae, at under Troens Lydighed maatte den færdes, naar den skulde bevæge sig sikkert, og ei i sin luftige Sværmen spotte Menneskets Helligdom og dybe Vished om en moralsk Natur og Forpligtelse (Grundtvig 1815a, $72 \mathrm{f}$.).

Forskellen på Ørsteds og Grundtvigs bedømmelser af Kant er indlysende: den ene knytter til ved Kants religionsfilosofi og accepterer dermed Kants rationalistiske udlægning af kristendommen, den anden benytter Kant som afsæt for kristentroen. Grundtvig er forsigtigt positiv, når det gælder Kants teoretiske filosofi, men i modsætning til sin samtids kantiansk prægede teologi, når det gælder spørgsmålet om fornuftens selvstændighed.

Grundtvigs strid med Ørsted er velbelyst i forskningen. ${ }^{2}$ Erland U. Jessen har peget på striden som eksempel på "litteraturen som social institution, som kommunikation og magtredskab" (Jessen 1971, 43) i offentligheden, et forhold, som ikke blot spiller en rolle i Grundtvigs strid med Ørsted, men $i$ et vist omfang også i de debatter, der analyseres i nærværende artikel.

Medens Grundtvigs forhold til den tyske idealisme og dens danske varianter er forholdsvis godt undersøgt, har meget få vist interesse for hans forhold til samtidens danske teologi. Men $V K 1812$ førte til, at Grundtvig reflekterede over sin position i forhold til såvel den teologi, der i perioden blev dyrket på universitetet og af ledende skikkelser indenfor den danske, evangelisk-lutherske statskirke, og i forhold til den,

\footnotetext{
${ }^{2}$ Striden behandles eksempelvis i C. I. Scharlings studie i Grundtvigs forhold til romantikken, i H. Høirups afhandling om Grundtvigs erkendelsesteori, i Erland U. Jessens artikel i Grundtvig-Studier 1971, i Erik M. Christensens Guldalderen som idéhistorisk periode: H. C. Ørsteds optimistiske dualisme 1966 og i Flemming Lundgreen-Nielsens disputats Det handlende Ord fra 1980, hvis teksthistoriske tilgang gør den til en uomgængelig grundbog, når det gælder studiet af Grundtvigs tidlige forfatterskab.
} 
der dyrkedes i de danske præstegårde. Et blik på Grundtvigs debatter med samtidige teologer nuancerer billedet af guldaldertiden som bestemt af idealistisk filosofi og bidrager samtidig til at profilere Grundtvigs teologiske position. Grundtvig har selv karakteriseret årene 1811 til 1815 som den "theologiske" periode i forfatterskabet. Karakteristikken tages op her, ikke fordi den er forfatterens egen, men fordi den er præcis og dækkende i forhold til Grundtvigs skriftlige produktion. Grundtvig siger i et utrykt tilbageblik fra 1824, af Holger Begtrup kaldt Brevveksling mellem Nørrejylland og Christianshavn, om den teologiske periode, at "al" hans "Skrift, fra den Tid, dreier sig om enfoldig Troe paa Skriften, som et aabenbart Guds Ord, og den deraf flydende Troe paa Jesum Christum, som det eneste Saligheds-Middel for syndige Mennesker" (US IV, 232-233). Denne karakteristik vidner om Grundtvigs ensidighed i disse år, men først når hans kristendomssyn sammenlignes med tidens akademiske teologi, forstår man, hvor radikalt anderledes han tænkte. Grundtvigs teologiske position adskiller sig fra de fleste samtidiges, selv om hans behandling af Kants tænkning vidner om, at han som sin samtids supranaturalisme var fristet af muligheden for at kombinere Kants sætten grænser for erkendelsen med en åbenbaringsbaseret teologi. Samtidig bliver det klart, at årsagen til Grundtvigs isolation i forhold til teologerne dels skyldtes hans vurderinger i VK 1812, dels hans reaktioner på de forsøg på imødekommenhed, som han oplevede fra ældre og etablerede teologers side frem til Danne-Virke-perioden i sit forfatterskab.

\section{Positioner i dansk og tysk teologi fra 0.1765 til o. 1812}

Op til i dag har opfattelsen af det 18. århundredes teologi været farvet af det eftermæle, som er blevet udformet i forbindelse med vækkelserne og revitaliseringen af klassisk kristendom i det 19. århundredes første halvdel. Også i vore dage kan man træffe på en unuanceret omtale af periodens teologi som "rationalisme", uden at der sondres mellem tidens forskellige retninger. Der er forbavsende få danske kirke- og teologihistoriske studier, der gennem omhyggelige undersøgelser af det tekstlige materiale forsøger at positionsbestemme de forskellige tendenser og gøre rede for deres teologi- og filosofihistoriske forudsætninger. ${ }^{3}$ Det

${ }^{3}$ Hal Kochs redegørelse i Den Danske Kirkes Historie bør nævnes (Koch 1954, $63 \mathrm{ff}$.). Der er ligeledes grund til at fremhæve Jens Glebe-Møllers Grundtvig og rationalisterne i Grundtvig-Studier 2011, 81 ff. Selv om Glebe-Møller under et betegner oplysningsteologerne som rationalister, er han bevidst om, at der forekommer forskellige positioner i oplysningsårhundredet og ind i det 19. århundredes første tiår. Hans opfattelse af, at "Grundtvigs teologi på væsentlige punkter var mere i slægt med rationalisternes, end han selv kunne se og ville være ved!" (Glebe-Møller 2011, 91), er en diskussion værd - også, selvom nærværende 
er dog muligt at levere en skitse, der kan tjene til orientering for den, der ønsker at tage emnet op.

Først sondringen mellem oplysningsteologiens former og retninger. Med kirkehistorikeren Michael Neiiendams monografi om den danske oplysningsteolog Christian Bastholm (1740-1819), suppleret med andre teologihistoriske undersøgelser og artikler, skelnes her mellem wolffiansk formidlingsteologi, neologi, rationalisme og supranaturalisme som en række positioner, der tidsmæssigt følger på hinanden, samtidig med at hver position lever videre og møder tilslutning fra teologer i kirken og på universitetet ind i det 19. århundredes første tiår. ${ }^{4}$ Det gælder ligeledes, at teologer i oplysningstiden og ind i det 19. århundrede på samme tid kunne knytte til ved og skabe en syntese af positioner, der ikke umiddelbart lod sig forene. ${ }^{5}$ Men samtidig repræsenterer positionerne fra wolffianisme til rationalisme hver for sig en tiltagende svækkelse i synet på den kristne åbenbarings karakter af gudsmeddelelse uafhængigt af den menneskelige tanke og dermed en tiltagende prioritering af fornuftens selvstændige virke. Den supranaturalistiske position opfattes her som en teologisk reaktion på rationalismen, der samtidig $\mathrm{i}$ et vist omfang knytter til ved kantiansk inspireret filosofi, samtidig med at man hos nogle af dens repræsentanter møder en videreførelse af Wolff-inspirerede tankemønstre.

Positionerne i det 18. og de første tiår af det 19. århundredes danske teologi lader sig ikke forstå uafhængigt af udviklingslinjerne i den tyske oplysningstænkning. Bestræbelserne hos filosoffen Christian Wolff (1679-1754) på at gøre rede for den menneskelige erkendelses muligheder og rækkevidde var udgangspunkt for teologernes overvejelser, samtidig med at teologiens selvstændighed og nødvendighed fastholdtes. Blandt

artikel forsøger at begrunde, at Grundtvigs tilgang til teologisk virksomhed i 1810 'erne adskilte sig markant fra oplysningsteologernes. Svagere end GlebeMøllers artikel står Troels Nøragers arbejde "Præsten og Loke - Grundtvigs apologetiske dialog i 'Om Christendommens Sandhed"'. Her kontekstualiseres Grundtvig historisk ved hjælp af amerikansk unitarisme, der for Nørager repræsenterer en “tidstypisk" position (Nørager 2012, 49 f.) - et mildest talt ejendommeligt greb, når der i en tysk og dansk protestantisk, med Grundtvig samtidig sammenhæng er langt mere nærliggende positioner, der burde inddrages.

${ }^{4}$ Denne skelnen må ikke skygge for, at der hersker terminologisk uklarhed indenfor teologihistorien, eksempelvis betegner den danske kirkehistoriker J. Oskar Andersen den Wolff-påvirkede teologi i det 18. århundredes midte hos danskerne Peder Rosenstand-Goiske (1704-69) og Ove Høegh-Guldberg (1731-1808) som en form for "Supranaturalisme" (Andersen 1904, 414).

${ }^{5}$ Det fremgår af Grundtvigs brevveksling med kapellanen ved Holmens kirke A. K. Holm (1767-1851), der til Grundtvig 31. marts 1813 kunne skrive om neologen Georg Joachim Zollikofer (1730-88) og den wolffiansk prægede Franz Volkmar Reinhard (1753-1812): "Zollikofer, Deres og min Reinhard anførde ei mange Sprog [skriftsteder] - prædikede da disse ikke Guds Ord?” (BG I, 150 f.). 
danske wolffianske formidlingsteologer står Sjællands biskop, Nicolai Edinger Balle (1744-1816) centralt, og hans frontstilling mod senere, mere radikale positioner som hos Otto Horrebow (1769-1823) betyder ikke, at han underkendte fornuften og dens evne til gennem egne midler at nå til indsigt $\mathrm{i}$ bevidsthedens og skaberværkets vidnesbyrd om Gud. ${ }^{6}$ Balle repræsenterer den gruppe vågne teologer i årene efter det 18. århundredes midte, der i vidt omfang støttede sig på Wolffs omfattende tyske og latinske filosofiske systemer, hvor sidstnævnte afhandlede den naturlige teologi $\mathrm{i}$ to halvbind. Her argumenterede Wolff for menneskets mulighed for gudserkendelse gennem tankelovene og betragtningen af skaberværket, altså gudserkendelse uafhængigt af åbenbaringen. ${ }^{7}$ Dermed ville Wolff ikke fratage den guddommelige åbenbaring betydning, men med Leibniz hævde, at nogle sandheder nok lå over fornuftens fatteevne, "au-dessus de la raison" (Leibniz 1710/1846, 23), men ikke derfor er ufornuftige. På den gryende oplysningstids teologer udøvede denne position en stærk tiltrækningskraft. Den tilkendte jo filosofien betydning, samtidig med at åbenbaringen i Kristus ikke derfor blev overflødig. Wolffs indflydelse kan spores langt op imod år 1801 og også derefter, al den stund den legitimerede teologi og forkyndelse i en tid, hvor den menneskelige fornuft var på vej til at få tildelt rollen som den eneste sande autoritet. Samtidig rummede den wolffianske tænkning en mulighed for yderligere frigørelse af den naturlige, menneskelige tanke, en stærkere betoning af fornuftens normative position, end Wolff intenderede. Om Friedrich Nicolai (1733-1811), udgiveren af den tyske oplysnings vigtige tidsskrift, Allgemeine Deutsche Bibliothek 1765 ff. (1793-1803 dog Neue Allgemeine Deutsche Bibliothek), skriver Neiiendam således, at han "repræsenterede den almindelige elastiske Wolffianisme", dvs.

Åbenbaringens Stadfæstelse af den naturlige Religion og en energisk Betoning af Enheden mellem Skrift og Fornuft, mellem åbenbaret og naturlig Religion (Neiiendam 1922, 66).

En sådan position åbnede samtidig portene for en stærkere betoning af fornuftens autoritet - underbetonedes åbenbaringens selvstændighed mere og mere $i$ en glidende proces, var vejen banet for at give den natur-

6 Til Balle, se Haslam 1998, 18 ff. Balle og Grundtvigs far Johan Grundtvig (1734 -1813) var svogre gennem Balles første ægteskab. K. E. Bugge har med rette peget på de forskellige kilder til Johan Grundtvigs teologi (Bugge 1965, 42 ff.) Med Gerald Haslams udgivelse af utrykt materiale fra Johan Grundtvigs hånd er der skabt grundlag for en mere præcis bestemmelse af linjer og inspirationer i Grundtvigs fars teologi, end det hidtil har været tilfældet.

7 Til en yderligere redegørelse for Christian Wolffs naturlige teologi se Neiiendam 1922, $47 \mathrm{ff}$. 
lige gudserkendelse og dermed fornuftens virksomhed en stærkere stilling, end den havde hos de ældre wolffianske teologer.

I udviklingen fra wolffiansk formidlingsteologi og frem til den egentlige filosofiske og teologiske rationalisme i slutningen af det 18 . århundrede møder man da en "Overgangsteologi[]", "som man har kaldt Neologien" (Brun 1911, 358). Indenfor denne "Oplysningens interimistiske Konsekvens" dominerer "Akkommodationstanken", stærkest hos Georg Joachim Zollikofer (1730-88) (jf. Neiiendam 1922, 78). Akkommodationstanken er teorien om, at de træk i Jesus af Nazarets forkyndelse, der for oplysningstidens mennesker syntes at være uantagelige for fornuften, af Jesus var indføjet $i$ hans tale for at komme hans jødiske samtid i møde, altså gøre antagelsen af hans budskab lettere for samtidens mennesker. Denne teori har haft et dårligt ry i eftertiden, men det må ikke sløre blikket for, at man her møder et tidligt forsøg på at tænke historisk-kritisk. Teorien forudsætter jo historisk bevidsthed: Jesu samtidige tænkte anderledes end oplysningstidens mennesker - en væsentlig iagttagelse, når der ses bort fra den naive holden Jesus af Nazaret fri af dette.

Akkommodationsteoriens blik for forgangne tidsaldres anderledeshed vidner da også om, at de teologiske legitimationsstrategier var i bevægelse i oplysningstiden. Udviklingen gik fra en oprindelig wolffiansk inspireret tillid til fornuftens naturlige gudserkendelse gennem tænkning, og det vil jo sige logikkens ahistoriske, eviggyldige sandheder, hen imod et forsøg på at grundlægge troen på historiske kendsgerninger, en bestræbelse, der på sigt måtte føre til brud med wolffianismen, selv om Wolff ikke vurderede, hvad han forstod ved historisk erkendelse, lavt. ${ }^{8}$

Hverken wolffiansk formidlingsteologi eller neologi må sammenblandes med, hvad der kan karakteriseres som den egentlige filosofiske

\footnotetext{
${ }^{8}$ Samtidig med at Christian Wolff prioriterede fornuftserkendelsen, agtede han den historiske erkendelse, der for ham, som påvist af Arno Seifert, i vidt omfang var identisk med den sansebaserede erkendelse. Ved at fremdrage og systematisere de betydninger, der frem til og med Kant er blevet lagt $\mathrm{i}$ den historiske erkendelse, "cognitio historica", påviser Seifert, at historisk erkendelse i det 18. århundredes begyndelse dækkede over 1) sansebaseret erkendelse, 2) erkendelse på grundlag af andenhåndsberetninger og 3 ) det område, menneskelig handlen afstikker. Han gør rede for, hvorledes disse historiens karakteristika "die logische Singularität ihrer Sätze, die Mittelbarkeit ihrer Erkenntnis und die Vorzugsbindung an die spezifische Materie der actiones humanae" (Seifert 1976, 178) udvikles til en skelnen hos Christian Wolff mellem historisk erkendelse og fornuftserkendelse som et vigtigt gennemgangsled. Historiebegrebet er i en linje over "Leibniz und Bacon" (179) knyttet sammen med "die Registrierung von Erfahrung schlechthin", der kan være tale om "diakronische Faktenzusammenhänge" (181), men først med Immanuel Kant bliver historiebegrebet som et diakront, altomfattende tidsforløb til.
} 
og teologiske rationalisme. Hovedskriftet er her Immanuel Kants Die Religion innerhalb der Grenzen der blossen Vernunft (1794). Her gør Kant rede for, hvorledes den religion, der alene er grundlagt på fornuften, må opfattes som den sande kristendom og dens tilhængere som den sande kirke:

Nun hat der historische Glaube (der auf Offenbarung als Erfahrung gegründet ist) nur partikuläre Gültigkeit, für die nämlich, an welche die Geschichte gelangt ist, worauf er beruht, und enthält, wie alle Erfahrungserkenntnis, nicht das Bewusstsein, dass der geglaubte Gegenstand so und nicht anders sein müsse, sondern nur, dass er so sei, in sich; mithin enthält er zugleich das Bewusstsein seiner Zufälligkeit. Also kann er zwar zum Kirchenglauben (deren es mehrere geben kann) zulangen, aber nur der reine Religionsglaube, der sich gänzlich auf Vernunft gründet, kann als notwendig, mithin für den einzigen erkannt werden, der die wahre Kirche auszeichnet (Kant 1794/1922, 167)

En konsekvent udnyttelse af Kants religionsfilosofi fører til en radikal teologisk position, hvor fornuften er restløst normerende i forhold til teologiske udsagn. Det forhindrer imidlertid ikke, at der er de første tiår af det 19. århundrede kan identificeres en række teologiske standpunkter, der præges af Kant uden at drage de fulde konsekvenser af hans tænkning. J. Oskar Andersen gør således rede for, at der "i Slutn. af 18. Aarh., under Indflydelsen fra Kant", danner sig "to teol.[ogiske] Skoler, der spiller en Rolle i de første Aartier af 19. Aarh og som nu selv benævner sig Supranaturalister og Rationalister". Med Neiiendams ord mente supranaturalisterne på baggrund af "Kants Påvisning af vor Erkendelses Begrænsning", at "en ny kristelig Trosforståelse" (Neiiendam $1922,82)$ blev sikret. I forlængelse heraf kan der peges på, at teologien kunne opfatte Kants ord i Kritik der reinen Vernunft om, at han måtte "das Wissen aufheben, um zum Glauben Platz zu bekommen" (Kant 1787/1956, XXX) som en legitimation af åbenbaringen. Men Neiiendam gør rede for, at den "bibelske Åbenbaring" hos de supranaturalister, der stod Kant nær, fremstod i "fornuftkontrollere[ $t]$ " form (Neiiendam 1922, 82). Også J. Oskar Andersen skriver, at

Denne "S.[upranaturalisme]" er en væsentlig Fortsættelse af det 18. Aarh.[undrede]s S[upranaturalisme], trods den nødv.[endige] Hensyntagen til Kant; den hævder Aabenbaringens Nødv.[endighed] og Overnaturlighed og finder den i Skriften, men i dens Fortolkning af Biblen spores Eftervirkningerne af Neologien (Andersen 1929, 417).

J. Oskar Andersen gør rede for, at man derfor har betegnet de mere oplysningsorienterede indenfor retningen som "Kryptorationalister", men at de "konservative Elementer blandt dem" er "afgjorte Bibelteologer", der kraftigt fremfører "det luth.[erske] Skriftprincip" (Andersen 1929, 417). I den sammenhæng skriver han, at 
I Nordtyskland staaer den ædle F. V. Reinhard (...) ikke blot som Bibelteologen, men som Fornyeren af Luthers Minde, og slaaer atter til Lyd for Retfærdiggørelseslæren som det centrale i den evang.[eliske] $\mathrm{Kr}$ [isten]$\mathrm{d}[\mathrm{o}] \mathrm{m}$ (Andersen 1929, 417).

J. Oskar Andersen jævnfører her den tyske teolog og prædikant Franz Volkmar Reinhard (1753-1812) med Grundtvig "i hans Stade som Bibelteolog" og føjer til, at Grundtvig "som saadan" hædrer "Reinhards Minde" (Andersen 1929, 417). Hvor Andersen synes at regne Reinhard til de Kantpåvirkede supranaturalister, bestemmer den nyere forskning ham som wolffiansk påvirket:

Als theol. Supranaturalist und phil. Wolffianer suchte er durch religiössittliche "Besserung" seiner Zuhörer einen Beitrag zur Emporbildung der Menschheit zu leisten. Den theol. Rationalismus, die Philosophie Kants, die radikale Franz. Aufklärung sowie den "wilden Eroberer" Napoleon lehnte er ab. Die modische Unkirchlichkeit und moralische Leichtfertigkeit seiner Zeit verstand er als Verfälschung der Ideale der Aufklärung. In Romantik und Dt. Idealismus sah er einen Rückfall in überwunden geglaubte Irrtümer (Schott 2003, 254).

Det vil i forbindelse med Grundtvigs debat med den danske teologiske professor Jens Møller blive klart, at det wolffianske element i Reinhards teologi bevirker, at Grundtvig kun i et vist omfang betragter ham som medkæmper - selvom Grundtvig, som påvist af Henning Høirup, i sin brug af kontradiktionsprincippet fra 1813 var påvirket af Wolff, betragtede han sig aldrig som en egentlig filosofisk eller teologisk wolffianer, et forhold, der eksempelvis kommer til udtryk i hans karakteristik af Wolffs tænkning som et forsøg på "at grunde en naturlig Vidskab, der skulde giøre Bibelen overflødig" (Grundtvig 1817, 435). I nærværende sammenhæng er det afgørende, at også "Rationalisterne" ifølge Andersen ligesom supranaturalisterne står som "Forsvarere for Aabenbaringen og Skriften”, men da, når der er tale om konsekvent kantiansk rationalisme, alene betragter "Aabenbaringen" som en "Genvej for Fornuftsreligionen" (Andersen 1929, 417).

Begge positioner var i begyndelsen af det 19. århundrede repræsenteret indenfor den danske universitetsteologi ved to professorer. Om disse skriver Grundtvig i Kirke-Speil (1861-63, trykt 1871), at det med de "to Møller'e, (som Baggesen kaldte "Vandmølleren" og "Vindmølleren")" forholdt sig sådan, at "den ene havde ingen Mening, og den anden ingen Myndighed" (US X, 349). Mølleren uden mening, der leverer det rene vand, er P. E. Müller (1776-1834), om hvem den teologiske professor H. N. Clausen (1793-1877) i sine erindringer skriver, at han som teologisk professor 1808-30 behandlede "Tros- og Sædelæren" uden "aandeligt Liv", men samtidig med "kantiansk Skarphed og Klarhed" (Clausen 1877, 62 f.). "Som Teolog" var Müller "bleven staaende ved 
Kantianismen og dens Indvirkning paa den teologiske Skole" (Clausen 1877, 141), havde altså ikke, som sin kollega Jens Møller, udviklet sig hen imod en position, hvor åbenbaringen i Kristus fyldte mere. ${ }^{9}$

Mølleren uden myndighed, der med sin teologi forfalder til vindmageri, idet ordet vind her bruges "om hvad der er tomt, betydningsløst, værdiløst ell. urigtigt" $(O D S)$, er førnævnte Jens Møller. Jens Møller holdt i sine år som teologisk professor ved Københavns Universitet 1808-33 gammeltestamentlige forelæsninger, men først og fremmest arbejdede han med kirkehistorien. H. N. Clausen skriver om ham som kollega i årene 1821-30, at "Det var i hine Aar, at Terminologien af Supernaturalisme og Rationalisme, Tvedelingen af supernaturalistiske og rationalistiske Teologer, Systemer og Skrifter, indforskreven fra Tyskland, var i den livligste Omsætning imellem Mand og Mand i den teologiske Verden". Clausens fremstilling er præget af en udtalt kritik overfor Møllers brug af begreberne, delvis foranlediget af, at Møller i sit tidsskrift karakteriserede Clausens eget standpunkt som "konsekvent Rationalisme". Karakteristikken fremkom "netop ved Udløbet af den femaarige grundtvig-lindbergske Fejdestrid" (Clausen 1877, 144), dvs. omkring 1830, og den Schleiermacher-påvirkede Clausen imødegik Møller, idet han påpegede, at brugen af de to begreber ikke lå fast, og at begreberne bød sig til som en nem udvej for de mange, der "helst" ville "have en Konklusion at løbe med uden Præmisser!" (145).

Det fremgår således af $\mathrm{H}$. N. Clausens erindringer, at de to begrebers dominans i dansk teologisk tænkning ligger efter F. V. Reinhards tid og dermed efter diskussionerne i forbindelse med $V K$ 1812. Dette støttes af, at Grundtvig i et udkast til anmeldelse i Theologisk Maanedsskrift omtaler "Striden mellem Super-Naturalisme og Rationalisme (mellem Aabenbarings-Troen og sammes Fornægtelse)" (Grundtvig 1826, Fasc. 116, 12, 3r). Men trods dette muliggør J. Oskar Andersens og Michael Neiiendams arbejder en teologisk kontekstualisering af Grundtvig, forudsat man som Neiiendam sondrer mellem wolffianisme, neologi, rationalisme og supranaturalisme. I en række debatter, hvoraf den første er indledt før udsendelsen af $V K$ 1812, der "udkom officielt ca. 30. dec." (SJ I, 76), blev Grundtvig nødsaget til at tage stilling til de fire nævnte

\footnotetext{
${ }^{9}$ Mellem P. E. Müller og Grundtvig var der også brevkontakt, således Grundtvigs skrivelse til professoren af 24. november 1812 og Müllers skarpe irettesættelse af Grundtvig for hans behandling af Jens Møller, "en Mand af fortrinlige Anlæg og Kundskaber og tillige af en saare elskværdig Karakter” (BG I, 115). Ved Müllers død i 1834 hilste Grundtvig ham dog som den næstsidste ægte nordiske oldforsker, idet han da regnede sig selv for den allersidste. Hans da ufuldførte sørgedigt blev først trykt i Danskeren 1848 med en nytilsat og optimistisk slutning på grund af Treårskrigen, der havde vakt danskerne til militær dåd (se LundgreenNielsen 2008, 237-250).
} 
teologiske positioner, og forud for udsendelsen af verdenskrøniken var han allerede indviklet $\mathrm{i}$ en debat $\mathrm{i}$ brevform om Kants teologiske rationalisme. I den af de efterfølgende debatter, der vejer tungest, debatten med førnævnte Jens Møller, indgår en stillingtagen til såvel rationalisme som Reinhards tidlige supranaturalisme. Og Georg Joachim Zollikofers neologiske position spiller en vis rolle i forbindelse med Grundtvigs debat med ovennævnte A. K. Holm, en debat, der udspiller sig på baggrund af Grundtvigs radikale teologiske princip, hvorefter enhver tankevirksomhed skal rette sig, princippet om, med Lutherbibelens oversættelse af 2. Kor 10,5, "at tage Fornuften fangen under Troens Lydighed". Endelig gives et glimt af den position, som stridighederne 1812-15 fører frem til, Grundtvigs Danne-Virke-position i årene 1816-19.

\title{
Kantiansk rationalisme: Grundtvigs debat med sognepræst Johan Harder
}

Den kantianske rationalisme mødte Grundtvig hos sognepræsten Johan Harder (1768-1831). Harder var født i Hertugdømmerne og uddannet i Tyskland (Wiberg 1870, 571). Alligevel blev han præst i kongeriget, i Radsted på Lolland-Falster, og Grundtvig har da sandsynligvis truffet ham gennem sin bror, provst Otto Grundtvig i Torkildstrup. Det fremgår af Grundtvigs breve, at han af Harder lånte Kants Die Religion innerhalb der Grenzen der blossen Vernunft, og hans refleksioner over værket i et brev til Harder 21. maj 1812 præges af en vis forbeholden anerkendelse. Selvom Grundtvig ikke finder Kants tanker om arvesynd og forsoning særlig dybsindige, betragter han ham som en skikkelse, der kalder den optimistiske oplysningsteologi til større alvor:

\begin{abstract}
Med en underlig blandet Følelse har jeg læst Bogen og mangengang forundret mig ligesaameget over Grubleren i Königsberg, som over hans Eftersnakkere. Hvormange saadanne der har været selv blandt hans navnkundige Tilhængere, lærer man af denne Bog ret. Hans Udsagn om den historiske Oprindelse og Fuldbringelse af Arvesynd og Forsoning have de godt nemmet, og det var ingen Sag, thi de ere platte og følge ligefrem af den al Tro ophævende Grundsætning Intet at vilde tro, uden hvad Man kan begribe

(...)

Troer De ikke, at ligesom Kant tugtede dem der i hans Tid snakkede om Forsoning og Naade uden at vise sig dygtige til at modtage dem, og vilde sagt til dem, der uden at have renset Hjertet raabe paa Moralitet og mene derved at fortjene Himmerig: trods al jer Snak om Dyd og gode Gerninger, gaa I dog den brede Vei ( $B G$ I, 75 f.).
\end{abstract}

Grundtvigs brev ligger forud for udsendelsen af $V K$ 1812, og den forsigtige sympati for Kant, der præger brevet, genfindes også i denne hans 
første verdenshistorie. I VK 1812 gør Grundtvig ganske vist rede for, at Kant "delte sin Tids Mistro til Bibelen", men at han samtidig ikke delte "dens Letsindighed", og at han "grundede alvorlig over Verdens Oprindelse og Menneskets Vilkaar”. For Grundtvig er den alvorligste brist ved Kants tænkning, at han, som religionsskriftet viser, ikke "kunde fæste Tro til nogen Aabenbaring udenfor sig", men han fremhæver, at Kant heller ikke "kunde eller vilde nægte den". Kants fremhævelse af erkendelsens grænser har hans sympati, Kant var "for ædru" til "at følge Fantasien" på dens flugt ud over, hvad der kan erkendes, men Grundtvig tolker samtidig königsbergeren sådan, at han med det kategoriske imperativ førte et fornuftens gudsbevis: "Er der en Lov i os, (...) som fordrer ubetinget Lydighed, saa maa der og være en Lovgiver" (US II, 331). Kants disciple har Grundtvig ikke meget tilovers for, "Faa forstode ham, Færre tilegnede sig det Bedste i hans Lære, men Desfleer skrege paa hans Navn" (332). I Grundtvigs kritik af kantianerne skimter man en teologisk anvendelse af Kant $\mathrm{i}$ forening med en suprarationalistisk fremhævelse af åbenbaringen:

Kant søgte Sandheden alvorlig, og derfor indsaae han, skøndt uden altid at følge det, at Man maa være ligesaa varsom i at forkaste, som i at antage; hans Eftersnakkere brøde sig kun lidt om Sandheden, men det var deres Lyst at synes kloge, at forkaste og nedrive Alt, hvad der havde været helligt i Lærdes og Læges Øine; Aabenbaring, Mirakler, Forsoning kaldte de umulige Ting, Guds Naade foragtede de og indskøde sig trodsende under hans Retfærdighed (US II, 332)

I Grundtvigs kritik indgår en implicit tilslutning til den lutherske lære om retfærdiggørelse af tro og ikke af gerninger. Grundtvigs tolkning af Kants etik som et "moralsk gudsbevis" og hans ord om, at Kant hverken antager eller forkaster åbenbaringen kunne have åbnet mulighed for, at Grundtvig byggede en åbenbaringsteologi op i kombination med kantiansk filosofi, men Grundtvig tænkte langt mere radikalt. Grundtvigs åbenbaringsteologi åbnede ingen mulighed for filosofiens selvstændighed - end ikke en begrænset selvstændighed, om end filosofien, som det fremgår af hans redegørelse for Kant, godt kunne rumme rigtige iagttagelser. Grundtvig må derfor have følt sig frastødt, da han i Johan Harders svar af 1. oktober 1813 mødte en talsmand for kantiansk rationalisme. Harders tilslutning til denne gren af oplysningsteologien har tilsyneladende ikke været Grundtvig bekendt, da han indledte forbindelsen med ham, men er først kommet til hans kundskab via korrespondancen. I Harders brev møder man således kantianismen i forbindelse med en rationalistisk vurdering af Luther og den lutherske reformation, en vurdering, der afviger markant fra Grundtvigs. Hvad Grundtvig må betragte som Luthers hovedanliggende, er for Harder historisk betingede udsagn, der står åbne for diskussion. For Harder gælder det, at Luther 
befattede sig [ved siden af kampen mod kirkelige misbrug og forkerte loerdomme] ogsaa med saadanne Troesartikler, som kunne omtvistes baade exegetisk og philosophisk; de bleve derfor ogsaa omtvistede, ei blot imellem Protestanter og Katholiker, men og imellem Protestanter selv, og blive det endnu, - saasom Arvesynd, Retfærdiggjørelse, Naade, Jesu Forsoning og Guddom, Nadverens Hemmelighed, Treenighed p.p. - men havde Luther allene holdt sig til disse, saa havde han aldrig fuldført sit store Værk, Reformationen, i hvor meget han end havde beraabt sig paa Biblen, thi da havde Ingen interesseret sig derfor eller taget synderlig deri, uden Theologer, og af dem allene havde Paven intet stort at befrygte.

(...)

Kort, for mig er det baade ved Fornuft og Kristendom en afgjort Sag, at Omvendelse med dens Frugter, Pligternes Opfyldelse af rene Bevæggrunde, Dydens Øvelse ved gode Gjerninger, er det Vigtigste, det ene, som er mest fornødent til Frelse for Sjæle (BG I, 182 ff.).

I Harders omtale af de "rene Bevæggrunde" er der genklang af Kants karakteristik af sand moralitet, hvor moraliteten ikke er bestemt af ydre tilbøjeligheder, bevæggrunde i rum og tid, men hvor subjektet ved at bøje sig for den lov, det selv udkaster, er borger i åndens verden. Harders konsekvente kantianske teologi var imidlertid langtfra den eneste samtidige teologiske position, Grundtvig blev nødsaget til at tage stilling til i 1810 ' erne.

\section{Akkommodationsteori og moderat oplysningsteologi: Grundt- vigs debat med A. K. Holm}

Hos Johan Harder mødte Grundtvig et egentligt Kant-påvirket rationalistisk stade. Derimod synes han ikke i årene omkring og efter udsendelsen af $V K 1812$ at have debatteret med neologisk orienterede teologer. Med daværende kapellan ved Holmens Kirke Andreas Krag Holm (17671851) står Grundtvig imidlertid over for en kritiker, der i sin teologi forenede påvirkninger fra flere forskellige sider og også forholdt sig til neologien. På baggrund af brev fra Grundtvig og med læsning af dele af Grundtvigs forfatterskab som forudsætning henvendte Holm sig til Grundtvig i et brev 31. marts 1813, der rummer både ris og ros. Forud for anerkendelsen går imidlertid en kritik af Grundtvigs for Holm alt for zelotiske kristendom og ivren for Bibelen, og her tilslutter Holm sig akkommodationsteorien:

Det lader sig dog vel bevise, at de hellige Skribenter have lempet sig efter Tidsalderens Begreber, at de have talt menneskeligviis for Kjødets Skrøbeligheds Skyld, og det var unægtelig Skriftfortolkernes Pligt at vise, hvor dette har været Tilfældet ( $B G \mathrm{I}, 155)$. 
I forlængelse heraf gør Holm sig til talsmand for en historisk bevidst bestræbelse på at "sætte sig ind i de Tider", hvori Bibelen "er skrevet". VK 1812 er den udløsende faktor i forbindelse med Holms kritik, men også Grundtvigs Dimisprædiken spiller en rolle, Holm angriber Grundtvigs kritik af "ubibelske Prædikener" og spørger i den sammenhæng, om "Zollikofer" og Grundtvigs - og hans - "Reinhard" ikke "prædikede" "Guds Ord", selvom de ikke "anførde" mange bibelcitater ("Sprog") (BG I, 150). Sammenstillingen af Reinhard og Zollikofer vidner om stor spændvidde i Holms teologi, men hans videre angreb på sin samtids mere ortodokse teologer placerer ham overvejende indenfor en form for moderat oplysningsteologi:

Hvorfor er den Klage i den senere Tid ført saa ofte, at man ei hører Guds Ord i Kirken? Vist nok er den kommen deraf, at man hørde løs og daarlig Tale om Livets Hverdagsting, Tale, hvorudi hverken Bibelens Aand eller Ord sporedes, - men det skeedte og, at hin Klage førdes, fordi man ei, som forhen, hørde den kjere Tale om Naade uden Gjerning, Salighed ved Tilegnelsen af Jesu Værdskyld alene. Man fandt sig nu ei saa let bestyrket i kjødelig Sikkerhed, men blev vakt af sin Dvale, nødt til at beskue sit Levnet, som i et Speil, man blev mindet om, at man ikke burde synde paa Naade, og at Kristus ikke kunde være Syndens Tjener - og nu raabde man: det er ikke Guds Ord - ikke om Gjerning, men om Tro og Naade ville vi høre. Unægtelig har vor Tidsalders Prædikemaade, saavelsom de forbigangne, sine Mangler, men lader os være billige, vi kunne gjøre Herrens Gjerning paa forskjellige Maader, men vi haane Ingen, der ikke gjør den, som vi. Lader os tænke paa 1. Kor. 3,12-14. Enhver see, hvad han bygger paa Grundvolden - der skal komme en Dag, der skal det aabenbare ( $B G \mathrm{I}, 150 \mathrm{f}$.)

Holm synes ikke at forkaste Kristi stedfortrædende lidelse som et led i kristendommen, men synes samtidig at acceptere forskellige linjer i teologien - den klassiske lutherdom, læren om retfærdiggørelse af tro, som han gengiver præcist, og en forkyndelse, hvor gerningerne, moraliteten, står i centrum. Denne åbenhed medfører, at Holms egen teologi ikke har klare konturer og i en vis forstand kan opfattes som et eksempel på, hvad J. Oskar Andersen kalder kryptorationalisme.

Holm står således oplysningsteologien nær, men hans fortsatte debat med Grundtvig viser samtidig, at han ikke uden videre kan betragtes som teologisk rationalist. Gennem et anonymt indlæg i heftet af Molbechs tidsskrift Athene for juni 1814, "Et Par Ord om at tage Fornuften fangen under Troens Lydighed" (489-520), "vendte" Holm "sig lidenskabsløst og principielt udtrykt mod Grundtvigs 1811-landemodetale", dvs. "Et Par Ord om Gejstlighedens Videnskabelighed eller om kristelig og præstelig "Lærdom". Holms "Indlæg[] plæderer", som Flemming Lundgreen-Nielsen skildrer det, "for et skel mellem tro og fornuft som det usynliges og det synliges område og for en historisk relativerende forståelse af Bibelen (herunder retten til bibelkritik)". Indlægget kan altså forstås 
således, at Holm på supranaturalistisk vis bestræber sig på at holde et område åbent for troen - og da også åbenbaringen - selv om "fornuften" med Flemming Lundgreen-Nielsens ord "tillægges en selvstændig rolle i tros-anliggender" (1980, 620 f.). For Grundtvig er fornuften ikke selvstændig - den skal, med Lutheroversættelsen af 2 Kor 10,5, tages fangen under troens lydighed, et forhold, Grundtvig gør rede for i pjecen Skal vi tro paa Gud eller paa Athene? eller om Tro og Fornuft under inddragelse af sin treleddede psykologi, hvor følelsen og forestillingsevnen har forrang frem for tanken og dermed fornuften:

Den troende Fornuft, Fornuften, som trods Hjertets stærke Attraa efter at omfavne Verden og udtømme den i Nydelse, troer paa den dybe Følelse, at Verden skal fornægtes af Kiærlighed til den levende Forestilling af Gud som Skaber og Fader, denne levende Fornuft maa nødvendig erkiende sin Trang til Oplysning i Livets Vilderede, til en Tro som kan forsone det syndige Menneske med sin Gud, til en Kraft, som kan betvinge Hjertets syndige Rørelser, og virke Kiærlighed til Gud og hans Villie (Grundtvig 1814a, 15).

Underlægger fornuften sig troen, vil den for Grundtvig at se nå til indsigt $\mathrm{i}$ forsoningens nødvendighed. Fornuften er for Grundtvig ikke en selvstændigt dømmende instans, som den til en vis grad er for Holm. Også for Grundtvigs betydeligste modstander i disse år, universitetsteologen Jens Møller, er det afgørende, at fornuften ikke sættes ud af kraft, selv om Grundtvig her møder en mere afgjort bestræbelse på at videreføre tanken om forsoningen ved Kristi kors som et hovedpunkt i evangeliskluthersk teologi, en position, der kan siges at repræsentere, hvad J. Oskar Andersen karakteriserede som afgjort bibelteologi.

\section{Tidlig supranaturalisme og forsoningstro: Grundtvigs debat med Jens Møller}

Jens Møller betegnede sig, som det fremgår af $\mathrm{H}$. N. Clausens erindringer, i sine senere år som supranaturalist, og Grundtvigs og Møllers diskussioner i breve ovenpå udgivelsen af VK 1812, afdækker, at Møllers position her var ved at få konturer allerede i 1810'erne. Bestræbelserne på at sikre åbenbaringens nødvendighed og da også at skabe rum for den klassiske lutherske synd-nåde-teologi møder man i Møllers breve til Grundtvig i disse år. ${ }^{10}$

Men var der da hos Møller tale om en wolffiansk eller kantiansk påvirket supranaturalisme? Knud Bannings karakteristik af Møller i den københavnske universitetshistorie synes at vidne om en teologisk position,

\footnotetext{
${ }^{10}$ Til Grundtvigs forhold til Jens Møller, se endvidere Toldberg 1945 og Albeck 1957.
} 
hvor den wolffianske formidling mellem fornuft og åbenbaring videreføres, idet den leibnizske skelnen mellem de sandheder, der er forståelige for fornuften, og de sandheder, der er over, men ikke imod fornuften, spøger i baggrunden. Banning gør rede for, at "Fornuften er (...) den evne, hvormed" mennesket for Jens Møller "kommer til troen", og at "åbenbaringstroen" for Møller "kun" kan "forsvares med fornuftens hjælp". Ifølge Banning kritiserer Møller rationalisterne for at "ophøje fornuften over åbenbaringen" med det argument, at "åbenbaringen - læs: Skriften - er (...) et værk af den guddommelige fornuft” (Banning 1980, 306).

Møllers position er da ikke ulig F. V. Reinhards, en teolog, der, som det fremgik af J. Oskar Andersens karakteristik af supranaturalismen, havde Grundtvigs agtelse, om end han også kritiserer ham. Grundtvig skriver i VK 1812 om Reinhard, at han står som et "Mindesmærke[] for den henrundne Tidsalder og som Forløber[] for et nyt". Det nye er, hvad Grundtvig håber, vil bryde frem med det 19. århundrede. Han er, som også digtet Frants Volkmar Reinhards Minde (US III, 98 ff.) fra 1812 vidner om, begejstret for Reinhards appel til samtiden om i tiden frem til reformationsjubilæet 1817 at huske på, at Luthers egentlige anliggende var forkyndelse og ikke blot frigørelse fra den katolske kirkes misbrug, frigørelse, der ifølge Johan Harders bedømmelse i oplysningstiden fortolkedes ud fra tidens ønske om at nå frem til fornuftig kristendom. Grundtvigs kritik af Reinhard i $V K 1812$ retter sig mod, at dennes forfatterskab, ved siden af den "kristelig[e] Tale", han førte, "udenfor de egenlige Troesartikle" præges af "Ligheden mellem hans og Tidens Tankegang" (US II, 354). Dette "beviser at hans Tydelighed i det Enkelte ei er blevet Klarhed i det Hele", hvorfor han "ei er enig med sig selv". Grundtvig slår fast, at det gælder for samtidens kristne, at "Hjertets Trang og Længsel har drevet dem til Kristus, men" at "Forstanden er i Tidens Vold", der bl.a. afsløres, "naar de dømme om (...) videnskabelige (...) Ting". Reinhards "hele Tankegang" og andres med hans - Grundtvig nævner Friedrich Leopold zu Stolberg (1750-1819) - er derfor "ei blevet kristelig", selvom han og de har troen i hjertet. Grundtvigs dom over Reinhard bygger på, at han som de tidlige, wolffiansk prægede teologer tilkender fornuften selvstændig virksomhed - om end han i nyere tysk biografisk litteratur karakteriseres som "Supranaturalist" og ikke som formidlingsteolog.

Reinhards tilsyneladende usammenhængende bevægelser mellem tro og (selvstændigt virkende) fornuft genfinder Grundtvig i Jens Møllers Theologisk Bibliotek, påbegyndt i 1811 blandt andet med den hensigt at præsentere nyere teologisk litteratur for danske præster. Om tidsskriftet kan man i verdenskrønikens rettelsessektion læse, at "det gaaer vexelvis paa alle Veie", og Grundtvig nøjes ikke med at kritisere, men giver også Møller råd om, hvordan tidsskriftet kan forbedres. Ville "det vænne sig til at gaa sagte og sikkert og ei bryste sig, da kunde det blive 
godt", skriver han, men føjer til, at "ingen Deltagelse spores" (US II, 450), dvs. at det ikke umiddelbart slog an i offentligheden.

Det kan ikke undre, at Jens Møller reagerede med temmelig megen ironi, da Grundtvig sendte ham to bidrag, heriblandt afhandlingen "Et Par Ord om Gejstlighedens Videnskabelighed eller om kristelig og præstelig Lærdom" til optagelse i tidsskriftet. Møller skrev 25. marts 1813 til Grundtvig, at han "mindst kunde (...) vente", at Grundtvig "vilde beære et Skrift med Deeltagelse", som han i VK 1812 regnede "blandt dem, der ingen Omtale fortjente", et tidsskrift, der manglede "sikker og fast Gang" $(B G \mathrm{I}, 136)$. Et sådant tidsskrift, skrev Møller, burde lige så lidet "smigre sig med selvstændige Skribenters Understøttelse, som christelig Ydmyghed burde forene sig med en Redacteur, der saaledes bryster sig," som han i Grundtvigs "Øine ansees for at giøre", dog "lykkeligviis" også kun i dem. Møller føjede til, at "Eensformighed ei heller i Fremtiden" ville "kunne findes i Biblioteket". Tidsskriftet skulle stå "aabent for alle tænkende og christelige Theologer af de forskjellige Skoler og Confessioner" og ville derfor gå "vexelviis paa forskjellige, om just ikke paa alle Veie". Han pointerede i tilslutning hertil, at Grundtvig "neppe" ville kunne opdage "nogen Modsigelse" i hans "egne Afhandlinger".

Grundtvig svarede 6. april 1813 skarpt, at Møllers "Indgang" i brevet ikke var ham "kiær", og spurgte, "hvortil" "saadan Ironi" skulle "være nyttig". Han føjede til, at han ikke kunne ændre sin dom om Møllers tidsskrift, og gjorde sin stilling klar:

At jeg har sagt det [Theologisk Bibliothek] gik vexelviis paa alle Veie, kan jeg ikke tage tilbage (...) Jeg havde nemlig dengang i Tanker to Stykker, som nok staa i eet Bind: Reinhardts Bekiendelser og, jeg husker ikke hvis, Afhandling om Slacgtskabet mellem Dyder og Laster (...) [hvori stod at loese, at] man skal være ydmyg for Loven men ikke for Lovgiveren, for $\operatorname{Gud}(B G \mathrm{I}, 171)$.

I sin diskussion af afhandlingen, hvor slægtskabet mellem dyder og laster behandles, gør Grundtvig sig skyldig i den fejltagelse at karakterisere forfatteren som en "rasende Pantheist" ( $B G$ I, 171). Forfatteren var den tyske rationalistiske teolog Heinrich Gottlieb Tzschirner (17781828), og selve artiklens terminologi, hvori ord som "Maxime" og "Agtelse" indgår, vidner om, at man her står overfor en kantiansk inspireret teolog:

Formedelst sin Frihed kan Mennesket bestemme sig til at handle efter Grundsætninger og Maximer, og jo oftere han i visse eensartede Tilfælde retter sig efter een og samme Grundsætning eller Maxime; desto lettere bliver det ham, naar disse Tilfælde vende tilbage, at følge samme Grundsætning eller Maxime, idet saavel Agtelsen som Ikke-Agtelsen for Loven befæstes ved den gjentagne Iagttagelse eller Krænkelse af samme; og 
derved opkommer en Tilbøielighed, til enten at opfylde eller overtræde Budet i lignende Tilfælde (Tzschirner 1812, 111).

Tzschirner var kantianer, men han var samtidig også supranaturalist men da supranaturalist i den forstand, at han forsvarer, hvad J. Oskar Andersen kaldte for kryptorationalisme. Tzschirners teologi blev bl.a. formet gennem en kontrovers med F. V. Reinhard, der havde hævdet, at en ren supranaturalistisk eller ren rationalistisk position var de to eneste konsekvente måder at drive teologi på. Heroverfor søgte Tzschirner at fastholde en mellemvej, hvor både åbenbaring og fornuft tilgodesås. Han fastholdt således ifølge teologihistorikeren Gustav Frank, at

Das Christenthum ist eine durch Wunder beglaubigte Offenbarung Gottes. "Hätte Christus nichts Außerordentliches gethan, und erwähnte die evangelische Geschichte keine von dem gewöhnlichen Laufe der Dinge abweichende und aus den Gesetzen der Natur nicht zu erklärende Begebenheiten, so würden die Menschen nie darauf gekommen sein, das Christenthum als eine außerordentliche Anstalt Gottes zu betrachten." Die Offenbarung bezweckt aber nicht die Bekanntmachung des der sich selbst überlassenen Vernunft Unerkennbaren, sondern die Kundmachung und Fortpflanzung der wahren Religion oder der religiösen Ideen und sittlichen Gesetze, die, im Bewußtsein des Menschen vorhanden, doch einer Weckstimme und Bestätigung von Aussen bedürfen. Der Vernunft gebührt Vertrauen auch in göttlichen Dingen, aber nie wird eine Philosophie das Evangelium, nie eine Schule die Kirche ersetzen können. So erscheint T. als Repräsentant des supranaturalen oder offenbarungsgläubigen Rationalismus (Frank 1895, 62 ff.)

For Tzschirner udsiger åbenbaringen ikke mere, end hvad der er i den menneskelige fornuft. Men medens fornuften for Kant ikke behøvede en ydre guddommelig bistand, mener Tzschirner, at en sådan er nødvendig, og at det er her, forkyndelsen i kirken har sin egentlige opgave. Men at Tzschirner lod åbenbaringens indhold være det samme som fornuftens, førte år senere Grundtvig til i artiklen "Om den sande Christendom" fra 1826 at kritisere dette, en kritik, der er indlejret i et generelt angreb på oplysningsteologien:

Saaledes tilstod, endnu 1810, den rationalistiske Theolog Tzschirner, som, mærkeligt nok, vilde slutte Kirkehistorien, at Rationalismen var en Overgang til Christendommens Fiender, hvorved man opgav Alt, hvad der var Christendommen egent, og beholdt kun den Fornuft-Religion, og de sunde moralske Grundsætninger, der hverken stod eller faldt med Jesus Christus og den christelige Aabenbaring: beholdt kun Skallen af den christelige Kirke, som en mærkelig [bemoerkelsesvardig] Ruin, ${ }^{11}$ Folk nu

${ }^{11}$ Dette er et citat af Oehlenschlägers Hakon Jarl, 1807, akt 4, brugt dér om asalæren af den kristne præst Tangbrand (jf. NM 1808, US I, 338). 
eengang var blevet vant til at besøge, og hvor man altsaa bekvemmest kunde holde sine moralske og deistiske Forelæsninger (US IV, 496).

Grundtvig har i 1813 muligvis ment, at Møller nærmede sig denne position. Men forst og fremmest vidner brevvekslingen om Grundtvigs vrede over Møllers kølige svar. Grundtvig føjede i sin svarskrivelse af 29. marts 1813 til, at Møller måtte "indrømme" ham, at en kommunikation uden "Stikleri", hvor man talte "Mand til Mand, og end mere Kristen til Kristen reentud", var "den eneste Rette" (BG I, 137). Samtidig sagde Grundtvig, at han forstod, "Fortørnelse" havde fået Møller til at skrive, som han skrev, og gjorde derefter rede for, at hans position i samtidens debatter, hvor han har taget sig "Verden til Fiende" (139), ikke var udsprunget af hovmod:

Tro dog ikke, at det er Tillid til min egen Forstand som giør mig saa dristig, ja om De vil saa myndig og haard mod anderledes Tænkende! Nei visselig, og troer De, det med en saadan Hovmod var i en vantro Tid muligt at underkaste hver sin Tanke Bibelens Myndighed. Nei, men jeg er overbeviist inderlig og urokkelig om at Jesus er Sandheden og Veien og Livet, og paa Hans Ord troer jeg fast at Skriften kan ikke feile og at hvo som ikke vil tro paa Guds eenbaarne Søns Navn er allerede dømt. Derfor maa Christi Kiærlighed tvinge mig (...) (BG I, 138 f.).

Grundtvig citerer således 2. Kor. 5,14 og udlægger dermed sin kompromisløshed som udslag af ønsket om, at evangeliet vil nå så mange som muligt. Den stejlhed, som Grundtvig fører tilbage til sin underkasten sig "Bibelens Myndighed" - og det vil sige Bibelen som normativ autoritet over alt andet, også fornuften - fører ham nu til at bedømme og i et vist omfang dømme - Møllers kristendom:

Hvad jeg nu troer om D.[eres] H.[øicervcerdighed]! skal jeg oprigtig sige Dem, jeg troer De i Henseende til Christum staar omtrent paa samme Punkt, som jeg indtil for at Par Aar siden. De troer ærlig paa Jesu overmenneskelige Natur som en Sandhed der hviler paa historiske Kiendsgierninger, men De ønsker at finde saa faa ubegribelige Ting at tro som muligt og vil derfor lade det Gamle Testamente staa ved sit Værd. De veed udentvivl ei ret, hvad De skal tro om Forsoningen, fordi De ikke ret inderlig har følt Menneskets høie Trang dertil, derfor seer De ikke det svælgende Dyb mellem Christendom og hvert System, der er Mænds Optænkning, derfor er De, hvad Man kalder tolerant. Har De nogensinde læst mine tidligere Afhandlinger om Religion og Liturgi og især den om Videnskabeligheds Fremme, da veed De, at jeg har tænkt saaledes, Deres egne Tanker veed De bedst selv, men jeg tager neppe feil, thi den Punkt Man selv har staaet paa, kiender man igien. At jeg beskylder Dem for Hovmod, synes haardt, men er det i min Mund ingenlunde. Jeg er vis paa at Hovmod er Menneskeslægtens Grundfeil, den vil raade sig selv, være selvstændig, som dog ingen uden Gud kan være, vi maa alle drages med den Djævel vor ganske Livstid, det føler jeg selv med Smerte mangengang, og det er ene den som hin- 
drer os fra at indsee vort Hjertes Fordærvelse, Vederstyggeligheden af det vi kalde vor Dyd for den Gud som seer inderligere til Tanken og Begicerligheden og hader det høie Hjerte, kort at føle vort Intet og vor Trang til uforskyldt Barmhjertighed i Christo Jesu ( $B G$ I, 139 f.).

Med omtalen af, at Gud kender menneskets tanker og tilbøjelighed, udøver Grundtvig sjælesorg over for Møller, hvad denne selvfølgelig ikke kunne acceptere. Grundtvigs karakteristik af Møllers position siger da også lige så meget om hans egen teologi som om dennes. Møller anerkender Jesu guddommelighed, og derfor regner Grundtvig ham som kristen. At kristendom altså står og falder med dette, betyder dog ikke, at der ikke er store mangler i Møllers tro - den helt afgørende forsoning gennem Jesu død og opstandelse spiller for Grundtvig at se ingen rolle for Møller, og at Møller ønsker at finde "saa faa ubegribelige Ting at tro som muligt" i Bibelen, vidner for Grundtvig om, at hans wolffianisme ligger nærmere neologien end den konservative formidlingsteologi, som mænd som biskop Balle repræsenterer. Bannings ord om, at Møller i sin teologi fremhævede åbenbaringens fornuftige karakter, viser i samme retning, og Grundtvig stiller skarpt på konsekvenserne heraf for Møllers opfattelse af Det Gamle Testamente. Baggrunden er her Møllers i Første Bind af Theologisk Bibliotek fra 1811 publicerede artikel "Om Forskjellen imellem den mosaiske og christelige Religions historiske Dokumentation". Møllers sammenligning af "Mosaismen og Christianismen" $(1811,83)$ er et spændende eksempel på, hvorledes akademisk teologi kunne se ud i det 19. århundredes første tiår. Møller afviser den op gennem århundrederne gængse "Inspirationstheorie" (86), dvs. "den hellig Aands Dicteren" (87) som forudsætning for Bibelens absolutte pålidelighed, og tilslutter sig den tyske oplysningsteolog Johann David Michaelis (1717-91), når det gælder bibelsynet. Michaelis opgiver inspirationsteorien i henseende til Ny Testamente, men fastholder alligevel beretningernes grundlæggende pålidelighed. Samtidig retter han en voldsom kritik mod Det Gamle Testamente: Mosebøgerne er ikke forfattet af Moses. Der er, når det gælder lovstoffet, tale om en udvikling over tid, og den troende jøde har derfor ikke samme sikkerhed i henseende til trosgrundlaget, som kristne har. At Møller for Grundtvig dermed vil lade Det Gamle Testamente "staae ved sit Værd", vil sige, at han hverken bestrider eller "godkender" Gammel Testamente, altså "i nogen grad er forbeholden ell. tvivlende" $(O D S)$ overfor værket, og dermed lader sin fornuft dømme og bedømme, hvor han skulle tro. Det "Hovmod", Grundtvig derfor mener at spore hos Møller, er ikke en bevidsthedsmæssig disposition i almen psykologisk forstand, men derimod dennes tillid til sin egen fornuft. Samtidig med at Grundtvig med tilslutning konstaterer, at Møller bygger sin tro på "historiske Kiendsgierninger", afviser han Møllers historisk-kritiske tilgang til den hellige skrift. Grundtvigs inddragelse 
af den gamle pagt vidner om, at han har læst Møllers førnævnte tekst i Theologisk Bibliotek, men han føjer mismodigt til, at han næppe formår at flytte på Jens Møller i dette spørgsmål:

At overbevise D.[eres] H.[øicervoerdighed]! om at jeg har Ret, at ogsaa De burde tro eenfoldelig baade paa det Ny og Gamle Testamente efter den ligefremme Mening, Man med sund Forstand seer deri, det kan vist ikke ventes $(B G \mathrm{I}, 140)$.

Samtidig forventer Grundtvig, at den "Time" skal "komme", hvor de "i Alt Vigtigt" vil "blive enige", for så sandt som Møller "troer ærlig paa Jesum og har annammet Sandhedskiærlighed", vil Gud vejlede "hvert saadant Menneske ved sin Hellig Aand til al Sandhed paa vores Viis". Grundtvig føjer til, at Møller er "een af de Mænd", han "saare nødig vilde være Uven med eller forbittre".

Jens Møllers svar til Grundtvig 3. april 1813 vidner om, at Grundtvig på afgørende punkter har skudt ham holdninger i skoene, han ikke har. Men samtidig tager Møller Grundtvigs anklage mod sig for hovmod og misforstår den som et angreb på sin moralske integritet. Og i samme åndedrag erklærer han, at han ikke blot fastholder troen på Jesu guddommelighed, men også den centrale lutherske understregning af Guds nåde som kristendommens grundanliggende. Møller gør rede for, at han "haaber", Grundtvig "feiler meget" i sin "Dom" om hans "Charakteer", når han "anklager” Møller "for Hovmod, og ikke vil forvende Ordenes Bemærkelse". "Hvor har jeg da pralet af min Dyd, eller nægtet, at jeg høiligen, som alle Msker, trænger til Guds Naade?”, spørger Møller og går derefter i rette med Grundtvig:

Jeg vil gjøre Dem opmærksom paa, at Ærgjerrighed kan boe ligesaavel hos den, der søger Trøst og Naade i Jesu Værdskyld, som hos den, der, foragtende al Naade, trodser paa sin egen Dyd, om ellers en saadan Vanartning skulde gives ( $B G \mathrm{I}, 161 \mathrm{f}$.)

Grundtvigs debat med Møller fortæller om to teologer i det 19. århundredes to første tiår, der, selvom de begge ønskede at stå den radikale oplysningsteologiske rationalisme fjernt, dog tænkte grundlæggende forskelligt. Den wolffianske inspiration hos Møller gik uproblematisk i spænd med hans historisk-kritiske bevidsthed og hans ønske om at grundlægge teologien ikke på en ahistorisk fornuft, men, som Grundtvig skriver, "paa historiske Kiendsgierninger" (BG I, 139). Deri var han og Grundtvig enige, men dermed hørte enigheden også op. Grundtvigs breve vidner om, at han i ét og alt betragter Bibelen, altså Det Gamle såvel som Det Ny Testamente, som en ufejlbarlig og uangribelig autoritet, og at han ikke anerkender Møllers bestræbelser på at forene kristentro med fornuftens anerkendelse af historisk-kritiske tilgange til den hellige skrift. 
Grundtvigs anklage mod Møller for at være hovmodig skal ses i dette lys - hovmodig er den, der vil lade sin fornuft beholde ret til at dømme, hvor mennesket $i$ et og alt skal underlægge sig troen. Men samtidig med, at Grundtvigs anklage skal ses i dette teologiske lys, rummer hans bedømmelse af Møllers tro og teologi også en række åbenbare urimeligheder. På sin side gjorde Møller sig imidlertid ligeledes skyldig i nogle fejlagtige anklager mod Grundtvig, da han "I juni-juli 1813" anonymt anmeldte VK 1812 i Dansk Litteratur-Tidende. Møller, der privat havde meddelt Grundtvig, at han var den anonyme recensent, kritiserede værkets mangel på "en fast og tydeligen gjennemtænkt Plan" (Møller 1813, 406) og ordner så sin kritik i fire dele: for det første er der fejl og udeladelser i de historiske fakta, for det andet har Grundtvig skrevet fremstillingen efter håndbøger uden kildestudier, for det tredje er hans kristent-lutherske sammenhæng vilkårligt og subjektivt tilvejebragt, og for det fjerde er den sproglige indklædning bogens "meest pletfrie Side" (458). Flemming Lundgreen-Nielsen, hvis sammenfatning her er fulgt, vurderer med Toldberg, at Møllers recension er "roligt skrevet, en fagligt orienteret og rimelig kritisk bedømmelse" (LundgreenNielsen 1980, 581). Samtidig med at denne vurdering, når det gælder de store træk, er præcis, har Grundtvig med rette kritiseret Møller for at skyde ham i skoene, at han vurderede alt i historien ud fra et evangeliskluthersk kirkeligt stade. Grundtvig pointerer i sit svar til Møller, at hans trosbegreb er bredere end som så, og skriver da:

Alt, hvad som ei er af Troen, er Synd, hvo som ikke i sin Tanke og Gierning adspørger Guds Villie, han synder, hvo som nu ikke engang troer paa Gud, er jo Syndens bundne Træl, og Den, som i et christent Land ei troer paa Christus, troer ei heller paa Gud, thi de, som ere af Sandhed, høre hans Røst, hvo som er af Gud, hører Guds Ord, det veed en Christen i Troen. Visselig gives der undskyldende Omstændigheder, og det vilde være uretfærdigt f. E. i vor Tid at dømme hver Uchristen saa haardt, som om han havde levet for 100 Aar siden, da Enhver hørte Ordet trindt [omkring] sig, da der var langt Mindre, som kunde forvirre og friste til Vantro, men dette maa slet ikke komme i Betragtning, naar vi vurdere en Mands offenlige Levnet, kun Dommen over hans Gemyt skal det formilde, dersom vi finde Spor af et Sindelag, der bøiede sig mod Sandhed og Dyd. At jeg ikke har glemt saadanne Hensyn, som Guds Ord tillader os at tage, kan blandt andet sees af min Dom over Kant og Fichte, Mænd jeg maatte dømt anderledes haardt, dersom jeg kun havde spurgt, jeg vil ikke sige om deres Forhold til Kirketroen, men om deres Tro paa de hellige Skrifter. Allerede dette viser hvor grundfalsk den Beskyldning er, at jeg har dømt Mænd efter Kirketroen

(...)

Derfor agter og elsker jeg ikke faa Mænd i vor Tid, skiøndt de ikke ere Christne, thi i vor Tid kan der midt i Europa være gudfrygtige Hedninge, 
som $\mathrm{i}$ en anden Tidsalder vilde være troende Christne, og som før deres Udgang vil vorde det, naar Guds Time kommer (Grundtvig 1813b, sp. 1060).

Grundtvig ender dog med at gøre det klart, at Møllers "Slutning har glædet og rørt" ham, Møller taler her "sande og alvorlige Ord" "om Troens Tvang og Tarv", ja, "Talen røber en Mand, der af egen Erfaring veed hvad Gudsfrygt duer til" (sp. 1075). Citatet fortæller videre, at det billede af Grundtvig som gammelluthersk konfessionalist, der tegnede sig for Møller og andre, ikke var helt præcist. Grundtvig lod i sin bedømmelse af samtidige ikke altid uden videre disses forhold til kristendommen være det udslaggivende, men var med sit brede trosbegreb på vej mod en mere afdæmpet, mindre hektisk forkyndende position - den position, han indtager i sit tidsskrift Danne-Virke.

\section{Afslutning: Grundtvigs Danne-Virke-position}

Hen imod slutningen af 1815 bevæger Grundtvig sig fra sin "theologiske" til sin "historiske" periode i forfatterskabet, hvor ikke den direkte forkyndelse, men den historiske "Erfaring", der kan gøre mennesket " $k \log [t]$ " (Grundtvig 1824/1948, 64), dominerer forfatterskabet. Ingen har bedre end Flemming Lundgreen-Nielsen påpeget med en DanneVirke-artikel som eksempel, hvorledes dette tidsskrift, 1816-19, som Grundtvig selv fyldte med sine tekster, viser

afklaringen i Grundtvigs begrebsverden og væksten i hans medmenneskelighed efter afslutningen af den kirkelige virksomhed i de bibelkristne år. I VK 1812 var Grundtvig den strenge dommer, Guds selvbestaltede repræsentant, der med navns nævnelse angreb og fordømte den ganske politiske og åndelige histories hovedpersoner ud fra en snæver lutherdom, hele tiden med en underforstået bedreviden og et skarpt blik for fejl. I 1816 er han fra dommersædet gået med jævne og bevægede ord ind i historien, føler sig ét med den i fortid og fremtid og udtrykker sin solidaritet i betegnelser fra almindelige menneskers familieliv: alle forgangne slægter er vore fædre, de samtidige vore søskende, de kommende vore børn (US III 348 f). Han fører varm, mild og kristelig tale og korter udfaldene mod det 18 . århundrede og Napoleonstiden ned til fordel for det positive, udformningen af det 19. århundredes åndsliv (Lundgreen-Nielsen 1980, 697 f.)

Grundtvigs filosofi, som den udformes i disse år, er grundlagt på historien, den er at forstå som lig med de refleksivt indvundne erkendelser, som beskæftigelsen med fortiden afgiver. Samtidig kan den grundtvigske filosofi kontekstualiseres, i og med, at Grundtvigs udvikling frem til Danne-Virke-positionen er grundlæggende bestemt af de erfaringer, han gør i mødet med sine kritikere i årene efter udsendelsen af $V K$ 1812. Verdenskrøniken af 1814 er således i vidt omfang skrevet som et 
svar til to anmeldere af verdenskrøniken af 1812, "Secretair Molbech", Grundtvigs tidligere nære ven, og "Professor [Jens] Møller" (Grundtvig 1814b, X). Men samtidig med at Grundtvig angriber Møller, har de problemstilling til fælles - diskussionerne om forholdet mellem åbenbaring og fornuft, som førtes af teologer i det 19. århundredes første tiår. Grundtvigs bedømmelse af Kant i VK 1812 og i skriftet mod Ørsted rummer både kritik og anerkendelse. I skriftet Europa, Frankrig og Napoleon. En dansk historisk Betragtning fra 1815 dominerer de negative tilgange til Kant, og forbindelsen sluttes fra ham til Fichtes i 1792 anonymt udgivne Versuch einer Critik aller Offenbarung, et værk, der i kraft af den manglende forfatterangivelse til at begynde med blev tillagt Kant. Om Fichtes debuttekst skriver Grundtvig, at den for samtiden "soleklart" "beviisde at en Aabenbaring ei kunde fordre Troe paa Andet end hvad Fornuften begreb" (Grundtvig 1815b, 140 f.). Imidlertid dukker anerkendelsen af Kant op igen i Danne-Virke - men uden, at den königsbergske filosofs navn nævnes:

kun i Korthed maatte jeg minde om disse aabenbare Sandheder, for at man ei skal med noget Skin kunne sige det er en sværmerisk Paastand at den Tidsalder som vil begribe hvad den skal troe, og mener at noget er afbeviist naar man beviser at det er et Menneske ubegribeligt, at den er ingenlunde fornuftig eller philosophisk, men netop det Modsatte (Grundtvig 1816, 115).

Bag tekstsammenhængen ligger det berømte citat fra Kritik der reinen Vernunft, hvor Kant taler om, at hans intention med kritikken af den fornuft, der overskrider sine grænser og kræver erkendelse, hvor den ikke kan eller skal gøre det, er at skabe plads for troen. Genklange af Kant høres også, når Grundtvig i artiklen "Om det Philosophiske Aarhundrede" fra Danne-Virke slår fast, at "Fornuften, naar den vil bedømme hvad den ikke forstaaer, tager mærkelig feil, og forvilder hver som følger den". Ja, siger Grundtvig, det kan "bevises, at Fornuften hidindtil stedse naar den i Aandens Rige vilde gaae paa sin egen Haand, foer saare meget vild" (Grundtvig 1816, 116). Grundtvig skildrer, hvorledes det 18. århundredes filosofi mishandlede historien, herunder Kant, der "paastod dens Ugyldighed" (125). Hvor Grundtvigs tilslutning til Kants hævdelse af den menneskelige erkendelses grænser bygger på Kritik der reinen Vernunft, er Kants påstand om historiens ugyldighed at finde i hans Die Religion innerhalb der Grenzen der blossen Vernunft, hvor han peger på, at "der historische Glaube" kun har "partikuläre Gültigkeit", hvorfor "der reine Religionsglaube" (Kant 1794/1922, 167) må prioriteres, den filosofiske tro, der frem for en historisk åbenbaring bygger på fornuftens autonomi. Hvor Grundtvig kan give Kant en begrænset anerkendelse i henseende til dennes teoretiske filosofi, er han absolut afvisende, når det gælder Kants religionsfilosofi. Det 
medfører hans fuldstændige afvisning af en position som Johan Harders eller en rationalistisk supranaturalistisk teologi, som man møder den hos H. G. Tzschirner. Grundtvigs teologi er allerede i det 19. århundredes første tiår grundlagt på en historisk givet åbenbaring. Men selv om dette tilsyneladende muliggør en form for samstemthed med de supranaturalister, der fastholder åbenbaringen og forsoningslæren, gør der sig, som i Grundtvigs debat med Jens Møller, så store forskelle gældende, at en nærmere forbindelse ikke er mulig. Også i Danne-Virke argumenterer Grundtvig for den troende fornufts virke i teologiske spørgsmål, "en Fornuft med opladte Øine, en opvakt Fornuft, hvilket netop er det samme som en i Sandhed selvbevidst, sand aandelig Fornuft" (Grundtvig $1816,125)$. Det er den fornuft, der er nået til indsigt i troens supremati og derfor hverken kan anerkende Kants autonome fornuft eller Jens Møllers selvstændigt virkende, historisk undersøgende fornuft. Denne Grundtvigs teologiske position isolerer ham ikke blot i forhold til idealistisk prægede positioner som Molbechs og Ørsteds, men også i forhold til kantianske eller formidlingsteologiske supranaturalistiske positioner. Grundtvigs strid med teologerne i årene efter udsendelsen af $V K 1812$ nuancerer ikke blot billedet af hans forfatterskab som bestemt af modsætningsforholdet til den tyske idealisme, men fortæller også om, hvor forskellige positioner der gjorde sig gældende i den danske "Guldalders" første, afgørende tiår.

\section{Forkortelser}

$B G$ I-II: Georg Christensen og Stener Grundtvig (udg.) (1924-26), Breve fra og til Grundtvig, 1807-72, bind 1-2, København.

DLT: Dansk Litteratur-Tidende.

DV I-IV: Grundtvig, N. F. S. (1816-19), Danne-Virke, bind I-IV, København.

Fasc.: Fascikel, dvs. håndskriftskapsel i Grundtvig-arkivet på Det Kongelige Bibliotek.

GSV I-VI: Th. Balslev m.fl. (1944-64), Grundtvigs Sang-Voerk. Samlet Udgave, IVI, København.

MM: Svend Grundtvig (1877), Mands Minde 1788-1838. Foredrag over det sidste halve Aarhundredes Historie, holdte 1838 af Nik. Fred. Sev. Grundtvig, København.

NKjSk: Nyeste Skilderie af Kjøbenhavn.

PS I-IX: Svend Grundtvig m.fl. (udg.) (1880-1930), N. F. S. Grundtvigs Poetiske Skrifter, I-IX, København.

US I-X: Holger Begtrup (udg.) (1904-09), Nik. Fred. Sev. Grundtvigs Udvalgte Skrifter, I-X, København.

VK 1812: Grundtvig, N. F. S. (1812), Kort Begreb af Verdens Krønike i Sammenhoeng, København. 